\title{
EFFECTS OF THE ADDITION OF SUGARS ON THE THERMOSTABILITY OF BETANIN FROM BETA VULGARIS L.
}

\author{
GABRIELLE G. IZAGUIRRES ${ }^{1}$ \\ SACHA K. C. RODRIGUES ${ }^{2}$ \\ LAIIS S. DA SILVA ${ }^{3}$ \\ CAMILA P. GRANDINI ${ }^{4}$ \\ FRANCINE ANTELO 5
}

\begin{abstract}
O impacto da adição de açúcares na estabilidade das betaninas de Beta vulgaris L. (beterraba) durante o tratamento térmico entre 50 e $80^{\circ} \mathrm{C}$ e $\mathrm{pH} 5$ foi investigado. A degradação das betaninas pura e adicionada de $10 \%$ de sacarose e $40 \%$ de frutose seguiu modelo de cinética de primeira ordem e conforme aumento da temperatura, houve aumento dos valores da constante de degradação térmica $(\mathrm{Kd})$, redução na meia-vida e nos valores do tempo de redução decimal (D). Termodinamicamente, apresentando valores de variação de entalpia $(\Delta \mathrm{H})$ mais altos (entre 99,66 e 99,41 kJ mol-1) que o extrato com a adição de sacarose (entre 85,27 e $85,03 \mathrm{~kJ}$ $\mathrm{mol}^{-1}$ ) e controle (entre 78,85 e 78,61 $\mathrm{kJ} \mathrm{mol}^{-1}$ ), a incorporação de frutose foi mais promissora no aumento da estabilidade do extrato de betaninas. Os valores positivos para a variação da energia livre de Gibbs $(\Delta G)$ indicaram que a reação de degradação das betaninas foi não-espontânea e os baixos valores da variação de entropia $(\Delta S)$ para o extrato com frutose (entre 0,02 e $0,03 \mathrm{~J} \mathrm{~mol}^{-}$ ${ }^{1} \mathrm{~K}^{-1}$ ) indicaram que o estado do material estava próximo ao seu equilíbrio termodinâmico.
\end{abstract}

PALAVRAS-CHAVE: ESTABILIDADE; TERMODINÂMICA; SACAROSE; FRUTOSE; PIGMENTOS NATURAIS

${ }^{1}$ Acadêmico do curso de Engenharia Agroindustrial - Indústrias Alimentícias, Universidade Federal do Rio Grande, Campus Santo Antônio da Patrulha. Email: gabi.izaguirres@hotmail.com

${ }^{2}$ Acadêmico do curso de Engenharia Agroindustrial - Indústrias Alimentícias, Universidade Federal do Rio Grande, Campus Santo Antônio da Patrulha. Email: sachakilles@hotmail.com

${ }^{3}$ Engenheiro Agroindustrial, Universidade Federal do Rio Grande, Campus Santo Antônio da Patrulha. Email: lais.santos.05@hotmail.com

${ }^{4}$ Doutoranda em Química Tecnológica e Ambiental, Universidade Federal do Rio Grande, Campus Santo Antônio da Patrulha. Email: camilagrandini@hotmail.com

${ }^{5}$ Doutora em Engenharia Química, Professora do Programa de Pós Graduação em Engenharia Química e do curso de Engenharia Agroindustrial da FURG, Campus Santo Antônio da Patrulha. Email: franantelo@ gmail.com 


\section{INTRODUCTION}

Color provides the basic quality information for human perception, and directly influences consumer's acceptance and preference. It is the first quality attribute of food evaluated by consumers, and is therefore an important component of food quality relevant to market acceptance (Wu \& Sun, 2013). Minimizing loss of pigment during processing is a primary concern for the processing industry - continuous monitoring of color change during industrial processing is necessary to ensure product quality (Shao-qian et al., 2011).

Mathematical modelling of experimental data can accurately predict the progress of a chemical reaction taking place in a homogeneous liquid or semi-solid during thermal processing or storage, being very useful in many engineering applications, including process optimization. So, experimental studies and applications of various simplified models to predict and interpret kinetics parameters (reaction order, rate constant, activation energy) are needed (Figueira et al., 2011). The important value of kinetic models is to predict quality changes inside and outside the test temperature range and optimize thermal processes under given non-isothermal conditions (Lixia et al., 2015). Most food quality attributes changes during thermal process or during storage follow a first order reaction model (Figueira et al., 2011). Topuz (2008), Patras et al. (2010) and Peron et al. (2017) have all considered the degradation of color to follow first-order reaction kinetics.

Motivated by the current global trend of using natural pigments as colorants for food, a search for economically viable sources has been conducted (Rossi et al., 2011). In this context, betalains are natural pigments typically associated with plants of the order Cariofilales and the major commercially exploited betalain crop is red beet (Beta vulgaris L.) (Vulíc et al., 2013). They include two classes of pigments: red betacyanins and yellow betaxanthins (Castellar et al., 2003). The most common betacyanin is betanidin 5-O- $\beta$-glucoside (betanin), the major pigment in red beets (Azeredo, 2009).

In addition to their red color, betalains possess several desirable biological activities, including antioxidant, antiinflammatory, hepatoprotective, and antitumor properties (Georgiev et al., 2010). However, it is known that temperature has a strong influence on the stability of betanin and the half-life of heat decomposition of betanin depends on the $\mathrm{pH}$ value, oxygen and light. Although the stability of betanin is also influenced by the water activity value, the addition of sugars may provide a protective effect against pigment decomposition (Stintzing \& Carle, 2008; Kopjar et al., 2012).

The aim of this research was to evaluate the effect of sucrose and fructose incorporation during the thermal processing of betanin from Beta vulgaris $L$. in order to estimate the degradation kinetics parameters and the thermodynamic functions of activation.

\section{MATERIALS AND METHODS}

\subsection{PIGMENT EXTRACTION}

Samples of Beta vulgaris L. were collected in the city of Santo Antônio da Patrulha RS and betanin was extracted according to Drunkler et al. (2003), using $70 \%$ ethanol as the solvent (ratio 1:2 w/v). After extraction, the extract was vacuum filtered and stored refrigerated $\left(5.0 \pm 1.0^{\circ} \mathrm{C}\right)$ in amber bottles. The extraction was performed in a single batch in order to ensure that the same extract was used in all assays of thermal degradation, ensuring the same initial characteristics.

\subsection{THERMAL DEGRADATION}

For processing between 50 and $80^{\circ} \mathrm{C}, 0.5 \mathrm{~mL}$ samples of the betanin extract added by $40 \%\left(\mathrm{~m} \mathrm{v}^{-1}\right)$ of sucrose and $10 \%\left(\mathrm{~m} \mathrm{v}^{-1}\right)$ of fructose (Rubinskiene et al., 2005) were put into screw 
capped test tubes and placed in thermostatic baths (Oxylab OXY 208 Batch), protected from light. The samples were collected periodically, in triplicate, as per Peron et al. (2017) until half of the initial betanin concentration was reached for each temperature condition explored. The $\mathrm{pH}$ of the extract was adjusted to 5.0 by the addition of $1 \mathrm{M} \mathrm{HCl}$ (Kasvi pH meter K39-2014B) to ensure the stability of the betanins (Castellar et al., 2003)

The initial betanin concentration $\left(C_{B O}\right)$ and the concentration immediately after sample collection $\left(C_{B}\right)$ were determined for each temperature and the results were expressed as $C_{B O} / C_{B}$.

\subsection{BETANIN CONCENTRATION}

The betanin concentration $\left(\mathrm{C}_{\mathrm{B}}\right)$ was monitored spectrophotometrically (Bel Photonics Spectrophotometer SP 1105) using the absorbance at $538 \mathrm{~nm}$ and $600 \mathrm{~nm}$ according to Nilsson (1970) and was defined as (Equation 1):

$$
C_{B}=\frac{\left[O D_{538}-O D_{600}\right]^{*} D F}{1023}
$$

where $C_{B}$ is the betanin concentration $\left(\mathrm{mg} 100 \mathrm{~g} \mathrm{red} \mathrm{beet}^{-1}\right), \mathrm{OD}_{538}$ is the optical density of the sample at $538 \mathrm{~nm}, \mathrm{OD}_{600}$ is the optical density of the sample at $600 \mathrm{~nm}$ and DF is the dilution factor.

\subsection{DEGRADATION RATE CONSTANT}

The degradation rate constant of the betanin extract and $\mathrm{K}_{d}\left(\mathrm{~h}^{-1}\right)$ were estimated according to Equation 2 (Fogler, 2012), assuming first order reaction kinetics:

$$
\frac{d C_{B}}{d t}=-K_{d} C_{B}
$$

where $C_{B}$ is the betanin concentration $\left(\mathrm{mg} 100 \mathrm{~g}\right.$ red beet ${ }^{-1}$ ) and $t$ is the time $(\mathrm{h})$.

\subsection{HALF-LIFE VALUES}

The half-life $t_{1 / 2}(h)$ for the first-order degradation kinetic model is given by Equation 3 (Fogler, 2012):

$$
t_{1 / 2}=\frac{\ln 2}{K_{d}}
$$

where $K_{d}$ is the degradation rate constant $\left(h^{-1}\right)$.

\subsection{DECIMAL REDUCTION TIME}

The decimal reduction time $D(h)$ which is the time needed for a tenfold reduction of the initial concentration at a given temperature was determined by Equation 4 (Mercali et al., 2013):

$$
D=\frac{\ln 10}{K_{d}}
$$

where $K_{d}$ is the degradation rate constant $\left(h^{-1}\right)$.

\subsection{ARRHENIUS EQUATION}

The Arrhenius equation relates the temperature to the constant for the speed of elementary reactions, and allows the determination of the activation energy and the frequency factor for pigment degradation reactions, as expressed by Equation 5 (Fogler, 2012): 


$$
K_{d}=A \exp ^{\left(-E_{d} / R T\right)}
$$

where $K_{d}$ is the degradation rate constant $\left(\mathrm{s}^{-1}\right), A$ is the frequency factor $\left(\mathrm{s}^{-1}\right), \mathrm{E}_{\mathrm{d}}$ is the activation energy for the degradation reaction $\left(\mathrm{J} \mathrm{mol}^{-1}\right)$, $\mathrm{T}$ is the temperature $(\mathrm{K})$ and $\mathrm{R}$ is the gas constant equal to $8.314 \mathrm{~J} \mathrm{~mol}^{-1} \mathrm{~K}^{-1}$.

\subsection{THERMODYNAMIC ANALYSIS}

The activation enthalpy $\Delta \mathrm{H}\left(\mathrm{J} \mathrm{mol}^{-1}\right)$, the free energy of inactivation $\Delta \mathrm{G}\left(\mathrm{kJ} \mathrm{mol}^{-1}\right)$ and the activation entropy $\Delta S\left(\mathrm{~J} \mathrm{~mol}^{-1} \mathrm{~K}^{-1}\right)$, were calculated for each temperature studied and were obtained using Equations 6, 7 and 8 (Labuza, 1980):

$$
\begin{gathered}
\Delta H=E_{a}-R T \\
\Delta G=-R T \ln \left(\frac{K_{d} h}{k_{B} T}\right) \\
\Delta S=\frac{\Delta H-\Delta G}{T}
\end{gathered}
$$

where $E_{a}$ is the activation energy for the degradation reaction $(\mathrm{J} / \mathrm{gmol}), \mathrm{K}_{\mathrm{d}}$ is a degradation rate constant $\left(\mathrm{s}^{-1}\right), \mathrm{h}$ is Planck's constant equal to $6.6262 \times 10^{-34} \mathrm{~J} \mathrm{~s}^{-1}, \mathrm{k}_{\mathrm{B}}$ is Boltzmann's constant equal to $1.3806 \times 10^{-23} \mathrm{~J} \mathrm{~K}^{-1}, \mathrm{~T}$ is the temperature $(\mathrm{K})$, and $\mathrm{R}$ is the gas constant $\left(\mathrm{J} \mathrm{mol}^{-1} \mathrm{~K}^{-1}\right)$.

\subsection{STATISTICAL ANALYSIS}

Statistical significance was determined by one-way ANOVA followed by Tukey's multiple comparisons test ( $5 \%$ confidence level) using Statistica (data analysis software system) version 7.0 for Windows.

\section{RESULTS AND DISCUSSION}

The degradation of betanin from Beta vulgaris $\mathrm{L}$. between 50 and $80^{\circ} \mathrm{C}$, followed first-order reaction kinetics (Figure 1) in agreement with the studies of and Saguy et al. (1979), Mabit et al. (2008), Gonçalves et al. (2013) and Shaaruddin et al. (2017). Since pH 5 provided the greatest stability to the betanin extract of Beta vulgaris L., this condition was mantained to analyze the effect of the addition of $40 \%$ sucrose and $10 \%$ fructose on thermodegradation between 50 and $80^{\circ} \mathrm{C}$.

According Tonon et al. (2010), the higher the water content, the higher is the molecular mobility inside the food, which facilitates the physicochemical reactions of degradation. The high concentration of sugars in fruits preserves the stability of the pigments and this effect can be explained by the fact that high sugar concentration reduces water activity. Therefore, the incorporation of sucrose and fructose into the betanin extract could provide a gain in thermostability. Table 1 shows a comparison of the kinetics of degradation of the control betanin extract with that of extracts with added sugars.

The effects of the same sugar may be different due to the fact that there are differents matrices composition as well as on other food products properties and therefore, controversial results of the influence of sugars on stability have been reported (Rubbermann et al., 2006). Rubinskiene et al. (2005) reported that the addition of fructose at concentrations between 10 and $40 \%$ reduced the thermostability of the black currant anthocyanins extract while concentrations between 20 and $40 \%$ of sucrose were effective in increasing the half-life of the same extract.

For betanin extract, at $50^{\circ} \mathrm{C}$, there was a gain in the half-life, however, given low coefficients of determination (below 0.9), there was no positive effect on the addition of the conservants. At $60^{\circ} \mathrm{C}$, the additions of $40 \%$ of sucrose and $10 \%$ of fructose increased the half-life of the extract compared to the control extract in 26 and $20.7 \%$, in that order. However, for the two higher temperatures, in accordance with the kinetic analysis, only the addition of sucrose was effective, especially at $70^{\circ} \mathrm{C}$ (22.6\% increase in $\left.\mathrm{t}_{1 / 2}\right)$, since there was no significant difference between the half-life values in relation 
to that obtained for the control extract. This effect could be explained by the fact that sugar addition reduces water activity and it is known that low water activity stabilizes pigments like betanin. In the high water activity, the reactants are in solution and further dilution by water reduces the reaction rate by the law of mass action. So, according Karel \& Lund (2003), the reaction rate is proportional to the reactant concentration which decreases with increasing water content. The opposite behavior was observed when fructose was added to the extract at 70 and $80^{\circ} \mathrm{C}$. The combination of high temperatures and low inicial water activities may have caused the increase in the degradation rate constant

The inverse of the temperature was also correlated with the logarithm of the degradation rate constant using the Arrhenius equation and the activation energy was determined as $81.54 \pm 4.4,87.96 \pm 2.35$ and $102.345 \pm 2.41 \mathrm{~J} \mathrm{~mol}^{-1}$, for extracts pure, with $40 \%$ of sucrose and with $10 \%$ of fructose, respectively.

Thermodynamic parameters such as enthalpy, free energy and entropy can also provide important information about thermal degradation kinetics.

According to Georgieva et al. (2012) activation enthalpy $(\Delta \mathrm{H})$ shows the energy difference between the reagent and activated complex. Similar values for all conditions evaluated indicates that the energy barrier that must be overcome in order to achieve the transition state is similar. The positive sign of $\Delta \mathrm{H}$ means that anthocyanin degradation is an endothermic reaction, accompanied by the adsorption of heat.

Considering the free energy of inactivation $(\Delta G)$, which represents the difference between the activated state and the state of the reactants, the positive values indicated that betanin degradation is a non-spontaneous reaction and the similar values indicated similar degradation mechanisms under the different conditions for the same temperature. From the $\Delta \mathrm{H}$ and $\Delta \mathrm{G}$ values it was possible to determine the activation entropy $(\Delta S)$, that represents the change in disorder of molecules in the system and the negative values obtained show that that the molecules in the transition state are more organized than those at the initiation of the reaction, and therefore, formation of the activated complex is associated with a decrease in entropy (Labuza, 1980).

Thermodynamically (Table 2), the incorporation of fructose was more promising in increasing the stability of the betanin extract, since the $\Delta \mathrm{H}$ values (for all temperatures) were higher than those obtained with sucrose. In this way, there is a need for a high energy barrier to break the bonds. Furthermore, the values obtained for $\Delta S$ in this study were low, which, according to Georgieva et al. (2012), means that the state of the material is close to its own thermodynamic equilibrium and thus the material shows little reactivity and has undergone some kind of physical or chemical rearrangement in its initial structure, bringing it to a state close to its own thermodynamic equilibrium.

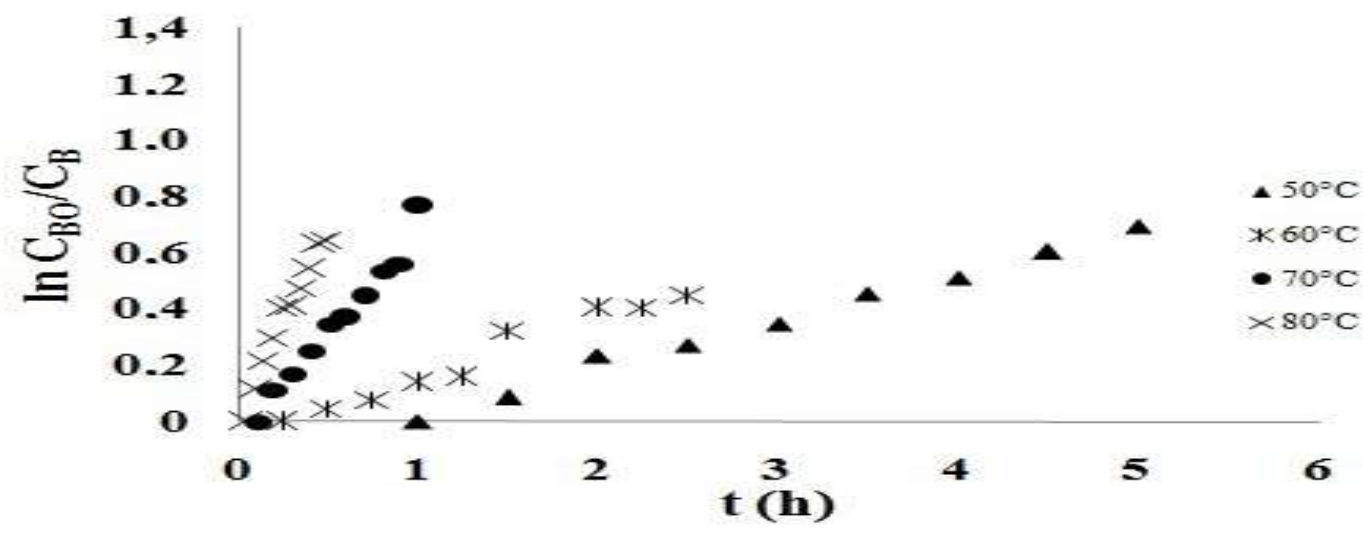

\section{FIGURE 1 - DEGRADATION OF BETANIN FROM BETA VULGARIS L. DURING HEATING BETWEEN 50 AND $80^{\circ} \mathrm{C}$ AT PH 5. EACH POINT REPRESENTS THE AVERAGE OF 3 REPLICATES AND THE STANDARD ERROR OF EACH POINT IS AROUND 5\%.}

${ }^{*} \mathrm{C}_{\mathrm{BO}}$ is initial betanin concentration ( $\left.\mathrm{mg} 100 \mathrm{~g} \mathrm{red} \mathrm{beet}^{-1}\right), C_{\mathrm{B}}$ is concentration immediately after sample collection (mg $100 \mathrm{~g}$ red beet $\left.{ }^{-1}\right)$ and $t$ is time $(h)$. 
TABLE 1 - EFFECT OF SUCROSE AND FRUCTOSE IN $K_{D}, T_{1 / 2}$ AND $D$-VALUES ON BETANIN DEGRADATION

\begin{tabular}{|c|c|c|c|c|}
\hline Sample & $\mathbf{T}(\mathrm{K})$ & $K_{d}\left(h^{-1}\right)^{* \star}$ & $t_{1 / 2}(h)$ & $D(h)$ \\
\hline \multirow{4}{*}{ Control } & 323 & $0.09 \pm 0.01(0.83)$ & 7.7 & 25.6 \\
\hline & 333 & $0.51 \pm 0.007(0.99)$ & 1.35 & 4.47 \\
\hline & 343 & $0.75 \pm 0,059(0.98)$ & 0.93 & 3.08 \\
\hline & 353 & $1.37 \pm 0.04(0.94)$ & 0.51 & 1.68 \\
\hline \multirow{4}{*}{$40 \%$ of sucrose } & 323 & $0.07 \pm 0.0036(0.75)$ & 10.13 & 33.66 \\
\hline & 333 & $0.41 \pm 0.009(0.93)$ & 1.7 & 5.66 \\
\hline & 343 & $0.61 \pm 0.02(0.93)$ & 1.14 & 3.78 \\
\hline & 353 & $1.3 \pm 0.03(0.94)$ & 0.53 & 1.78 \\
\hline \multirow{4}{*}{$10 \%$ of fructose } & 323 & $0.06 \pm 0.004(0.84)$ & 12 & 39.98 \\
\hline & 333 & $0.42 \pm 0.152(0.98)$ & 1.63 & 5.42 \\
\hline & 343 & $0.82 \pm 0.031(0.95)$ & 0.84 & 2.79 \\
\hline & 353 & $1.65 \pm 0.06(0.95)$ & 0.42 & 1.4 \\
\hline
\end{tabular}

"Kd: degradation rate constant;

$t_{1 / 2}:$ half-life;

D: decimal reduction time;

${ }^{* *}$ Numbers in parentheses are the correlation coefficients.

\section{TABLE 2 - THERMODYNAMIC PARAMETERS OBTAINED FOR BETANIN DEGRADATION WITH SUGARS ADDICTION}

\begin{tabular}{|c|c|c|c|c|}
\hline Sample & $\mathbf{T}(\mathrm{K})$ & $\Delta \mathrm{H}\left(\mathrm{J} \mathrm{mol}^{-1}\right)$ & $\Delta \mathrm{G}\left(\mathrm{kJ} \mathrm{mol} \mathrm{m}^{-1}\right)$ & $-\Delta S\left(\mathrm{~J} \mathrm{~mol}^{-1} \mathrm{~K}^{-1}\right)$ \\
\hline \multirow[t]{4}{*}{ Control } & 323 & 78.85 & 107.78 & 0.09 \\
\hline & 333 & 78.77 & 106.37 & 0.08 \\
\hline & 343 & 78.69 & 108.58 & 0.09 \\
\hline & 353 & 78.61 & 110.06 & 0.09 \\
\hline \multirow[t]{4}{*}{$40 \%$ of sucrose } & 323 & 85.27 & 108.51 & 0.07 \\
\hline & 333 & 85.19 & 107.02 & 0.06 \\
\hline & 343 & 85.11 & 109.17 & 0.07 \\
\hline & 353 & 85.03 & 110.22 & 0.07 \\
\hline \multirow[t]{4}{*}{$10 \%$ of fructose } & 323 & 99.66 & 108.98 & 0.03 \\
\hline & 333 & 99.58 & 106.90 & 0.02 \\
\hline & 343 & 99.49 & 108.31 & 0.02 \\
\hline & 353 & 99.41 & 109.51 & 0.03 \\
\hline
\end{tabular}

T: temperature;

$\Delta \mathrm{H}$ : activation enthalpy;

$\Delta \mathrm{G}$ : free energy of inactivation;

$\Delta S$ : activation entropy. 


\section{CONCLUSIONS}

Addition of $10 \%$ of fructose and $40 \%$ of sucrose had a positive effect on the stability of betanin, especially at lower temperatures between 50 and $80^{\circ} \mathrm{C}$, leading to an increase of the half-life value of the extract by up to $26 \%$ and consequently increase of the $D$ value and decrease of $K_{d}$. This effect could be explained by the fact that sugar addition reduces water activity and low water activity stabilizes pigments like betanin. The degradation of the extract under all conditions followed a first-order kinetic model and according the $\Delta \mathrm{G}$ and $\Delta \mathrm{H}$ degradation reaction is non-spontaneous and exothermic. From a thermodynamic point of view, fructose promoted stability more successfully than sucrose because the $\Delta \mathrm{H}$ values were higher than those obtained with sucrose and the low values of $\Delta S$ when incorporated this sugar means that the state of the material is close to its own thermodynamic equilibrium.

\section{ABSTRACT \\ EFFECTS OF THE ADDITION OF SUGARS ON THE THERMOSTABILITY OF BETANIN FROM BETA VULGARIS L.}

The impact of the addition of sugars on stability of betanin from Beta vulgaris $\mathrm{L}$. (red beet) by thermal treatment between 50 and $80^{\circ} \mathrm{C}$ and $\mathrm{pH} 5$ were investigated. The degradation of betanin pure and added by $40 \%$ of sucrose and $10 \%$ of fructose followed a first-order kinetic model and as the temperature was increased, there was an increase in degradation rate constant values $(\mathrm{Kd})$, a reduction in the half-life and the values of decimal reduction time (D). Thermodynamically, the incorporation of fructose was more promising in increasing the stability of the betanin extract, since the activation enthalpy values $(\Delta \mathrm{H})$ were higher (between 99.66 and $99.41 \mathrm{~kJ} \mathrm{~mol}^{-1}$ ) than those obtained with sucrose (between 85.27 and $85.03 \mathrm{~kJ} \mathrm{~mol}^{-1}$ ) and pure (between 78.85 and $78.61 \mathrm{~kJ} \mathrm{~mol}^{-1}$ ). The positive values of free energy of inactivation $(\Delta G)$ indicated that betanin degradation is a non-spontaneous reaction and the low values of activation entropy $(\Delta S)$ to extract with fructose (between 0.02 and $0.03 \mathrm{~J} \mathrm{~mol}^{-1} \mathrm{~K}^{-1}$ ) means that the state of the material is close to its own thermodynamic equilibrium.

KEYWORDS: STABILITY, THERMODYNAMIC FUNCTIONS, SUCROSE, FRUCTOSE, NATURAL PIGMENT

\section{REFERENCES}

1 AZEREDO, H.M.C. Betalains: properties, sources, applications, and stability - a review. International Journal of Food Science and Technology, v. 44, n. 17, p. 2365-2367, nov. 2009.

2 CASTELLAR, R.; ÓBON, J.M.; ALACID, M.; FERNÁNDEZ-LÓPEZ, J.A. Color properties and stability of betacyanins from opuntia fruits. Journal of Agricultural Food Chemistry, v. 5, n. 51, p. 2772-2776, mar. 2003.

3 FIGUEIRA, A.C.; MAKINDE, O.; VIEIRA, M.C. Process optimisation of sweet potato (Ipomoea batatas) puree as an ingredient in a formulation of weaning food. Fruit, Vegetable and Cereal Science and Biotechnology, v. 5, n. 2, p. 25-34, mar. 2011.

4 FOGLER, H.S. Elements of Chemical Reaction Engineering. New Jersey: Prentice Hall PTR, 2012. 853 p.

5 GEORGIEVA, V.; ZVEZDOVA, D.; VLAEV, L.. Non-isothermal kinetics of thermal degradation of chitosan. Chemistry Central Journal, v. 6, n. 1, p. 81-90, aug. 2012.

6 GEORGIEV, V.G.; WEBER, J.; KNESCHKE, E-M.; DENEV, P.N.; BLEY, T.; PAVLOV, A.I. Antioxidant activity and phenolic content of betalain extracts from intact plants and hairy root cultures of the Red Beetroot Beta vulgaris cv. Detroit Dark Red. Plant Foods for Human Nutrition, v. 65, n. 2, p. 105-111, jun. 2010.

7 GONÇALVES, L.C.P.; DI GENOVA, B.M.; DÖRR, F.A.; PINTO, E.; BASTOS, E.L. Effect of dielectric microwave heating on the color and antiradical capacity of betanin. Journal of Food Engineering, v. 118, n. 1, p. 49-55, sept. 2013. 
8 HUBBERMANN, E.V; HEINS, A.; STÖCKMANN, H.; SCHWARZ, K. Influence of acids, salt, sugars and hydrocolloids on the colour stability of anthocyanin rich black currant and elderberry concentrates. European Food Research and Technology, v. 223, n. 1, p. 83-90, may 2006.

9 KAREL M.; LUND, D.B. Physical principles of food preservation. New York: Marcel Dekker Inc, 2003. 639 p.

10 KOPJAR, M.; JAKSÍC, K.; PILIZOTA, V. Influence of sugar and chlorogenic acid addiction on anthocyanin content, antioxidant activity and color of blackberry juice during storage. Journal of Food Processing and Preservation, v. 36, n. 6 , p. 545-552, dec. 2012.

11 LIXIA, H.; BO, L.; SHAOJIN, W. Kinetics of color degradation of chestnut kernel during thermal treatment and storage. International Journal of Agricultural and Biological Engineering, v. 8, n. 4, p. 106-115, aug. 2015.

12 LABUZA, T. Enthalpy-entropy compensation in food reactions. Food Technology, v. 34, n. 1, p. 67-77, 1980.

13 MABIT, J.; BELHAMRI, R.; FAYOLLE, F.; LEGRAND, J. Development of a time temperature integrator for quantification of thermal treatment in scraped surface heat exchangers. Innovative Food Science \& Emerging Technologies, v. 9, n. 4, p. 516-526, oct. 2008.

14 MERCALI, G.D.; JAESCHKE, D.P.; TESSARO, I.C.; MARCZAK, L.D.F. Degradation kinetics of anthocyanins in acerola pulp: Comparison between ohmic and conventional heat treatment. Food Chemistry, v. 136, n. 2, p. 853-857, jan. 2013.

15 NILSSON, T. Studies into the pigments in beetroot (Beta vulgaris L. ssp. vulgaris var. rubra L.). Lantbrukshögskolans Annaler, v. 36, n. 1, p. 179-219, 1970.

16 PATRAS, A.; BRUNTON, N.P.; O'DONNELL, C.;TIWARI, B.K. Effect of thermal processing on anthocyanin stability in foods; mechanisms and kinetics of degradation. Trends in Food Science \& Technology, v. 21, n. 1, p. 3-11, jan. 2010.

17 PERON, D.V.; FRAGA, S.; ANTELO, F. (2017). Thermal degradation kinetics of anthocyanins extracted from juçara (Euterpe edulis Martius) and "Italia" grapes (Vitis vinifera L.), and the effect of heating on the antioxidant capacity. Food Chemistry, v. 232, n. 1, p. 836-840, oct. 2017.

18 ROSSI, T. Corantes Naturais: Fonte, Aplicações e Potenciais para uso da Madeira. IPEF- Instituto de Pesquisa e Estudos Florestais, 2008. Disponível em: <www.ipef.br/tecprodutos/corantes.asp>. Acesso em: 18 jan. 2018.

19 RUBINSKIENE, M.; VISKELIS, P.; JASUTIENE, I.; VISKELIENE, R.; BOBINAS, C. Impact of various factors on the composition and stability of black currant anthocyanins. Food Research International, v. 38, n. 8, p. 867-871, oct./nov. 2005.

20 SAGUY, I.; KOPELMAN, I.J.; MIZRAHI, S. Thermostability of red beet pigments (betanin and vulgoxanthin-I): influence of pH and temperature. Journal Food Science, v. 44, n. 2, p. 1554-1555, feb. 1979.

21 SHAO-QIAN, C.; LIANG, L.; SI-YI, P. Thermal degradation kinetics of anthocyanins and visual color of blood orange juice. Agricultural Sciences in China, v. 10, n. 12, p. 1992-1997, dec. 2011.

22 SHAARUDDIN, S., GHAZALI, H.S.; MIRHOSSEINI, S.H., MUHAMMAD, K. Stability of betanin in pitaya powder and confection as affected by resistant maltodextrin. LWT - Food Science and Technology, v. 84, p. 129-134, oct. 2017.

23 STINTZING, F.C.; CARLE, R. Food Colorantes: Chemical and Functional Properties. Boca Raton: CRC Press, 2008. $648 \mathrm{p}$.

24 TONON, R.V.; BRABET, C.; HUBINGER, M.D. Anthocyanin stability and antioxidant activity of spray-dried açai (Euterpe oleracea Mart.) juice produced with different carrier agents. Food Research International, v. 43, n. 3, p. 907-914, apr. 2010.

25 TOPUZ, A. A NOVEL APPROACH FOR COLOR DEGRADATION KINETICS OF PAPRIKA AS A FUNCTION OF WATER ACTIVITY. LWT - FOOD SCIENCE AND TECHNOLOGY, V. 41, N. 9, P. 1672-1677, NOV. 2008.

26 VULÍ́C, J.J.; CEBOVIíc, T.N.; CANADANOVÍC, V.M.; CETKOVÍC, G.S.; DJILAS, S.M; CANADANOVÍC-BRUNET, J.M.; VELÍCANSKI, A.S.; CVETKOVIÍC, D.D.; TUMBAS, V.T. Antiradical, antimicrobial and cytotoxic activities of commercial beetroot pomace. Food \& Function, v. 4, n. 2, p. 713-721, feb. 2013.

27 WU, D.; SUN, D.W. Colour measurements by computer vision for food quality control - A review. Trends in Food Science, v. 29, n. 1, p. 5-20, jan. 2013.

\section{ACKNOWLEDGMENTS}

The authors gratefully acknowledge the financial support of the Conselho Nacional de Desenvolvimento Científico e Tecnológico - CNPq. 